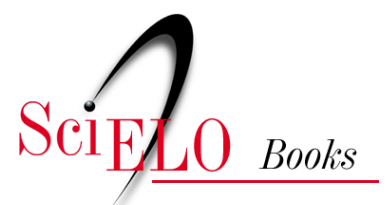

\title{
1 - Um menino do interior de Minas A boy from rural Minas Gerais
}

\author{
Simone Petraglia Kropf \\ Aline Lopes de Lacerda \\ Diane Grosklaus Whitty (trad.)
}

\section{SciELO Books / SciELO Livros / SciELO Libros}

KROPF, S.P., and LACERDA, A.L. Um menino do interior de Minas = A boy from rural Minas Gerais. In: Carlos Chagas, um cientista do Brasil = Carlos Chagas, scientist of Brazil [online]. Translated by Diane Grosklaus Whitty. Rio de Janeiro: Editora FIOCRUZ, 2009, pp. 24-41. ISBN: 978-65-5708-000-9. https://doi.org/10.7476/9786557080009.0005.

International license.

Todo o conteúdo deste trabalho, exceto quando houver ressalva, é publicado sob a licença Creative Commons Atribição 4.0. 
arlos Ribeiro Justiniano Chagas nasceu aos 9 de julho de 1878, na Fazenda Bom Retiro, a cerca de vinte quilômetros da cidade de Oliveira, Minas Gerais.

No século XVIII, a busca pelo ouro abriu muitas veredas no oeste mineiro. A "nova picada de Goiás" passava pelo local onde, à beira do rio Maracanã, iria se estabelecer Oliveira, em um cruzamento de vários caminhos. A origem do nome é atribuída ao português que, por volta de 1730, instalou uma pousada para descanso de tropeiros e viajantes. Duas décadas depois, os que ficaram na região erigiram um cruzeiro e, mais tarde, a capela de Nossa Senhora de Oliveira. Foi o núcleo do povoado que, em 1860, transformou-se em cidade.

Construída na segunda metade do século XVIII, a Fazenda Bom Retiro foi uma das primeiras propriedades estabelecidas em Oliveira, anterior ao povoado que daria origem à cidade. Com cerca de 7.700 hectares de extensão, tinha como atividades principais a pecuária de corte e leiteira e o cultivo de cana-de-açúcar e café. Possuía ainda plantações de milho e feijão e grande variedade de árvores frutíferas.

O bisavô de Carlos Chagas, Francisco das Chagas de Andrade, era natural dos Açores e chegou à região em meados do século XVIII. Dos muitos filhos que teve com Mariana Josefa Lobato, a primogênita, Romualda Chagas de Andrade, casou-se com um tenente português, Serafim Justiniano de Figueiredo. Tiveram muitos filhos, entre os quais José Justiniano Chagas, que seria pai de Carlos Chagas. A primeira esposa de José Justiniano faleceu precocemente e ele casou-se novamente, com Mariana Candida Ribeiro de Castro, cujo pai, Carlos Ribeiro de Castro, possuía fazendas na região, entre as quais a Bom Retiro.

Carlos Chagas foi o primeiro dos quatro filhos do casal. Tinha 4 anos quando o pai faleceu. A mãe assumiu, então, a administração do cultivo do café na Fazenda Bom Retiro e também na Fazenda Bela Vista, que José Justiniano havia adquirido nas proximidades de Juiz de Fora.

A convivência do menino com seus tios maternos, Cícero, Olegário e Carlos - o "tio Calito" era médico formado no Rio de Janeiro e dono de uma casa de saúde em Oliveira -, fez com que ele manifestasse, desde cedo, vontade de avançar nos estudos, com particular interesse pela medicina. Aos 8 anos, já alfabetizado, foi matriculado no Colégio São Luís, dirigido por jesuítas em Itu, interior de São Paulo. Fundado em maio de 1867, foi o segundo colégio criado por essa ordem religiosa no país - o primeiro havia sido fundado em Santa Catarina. Era um dos mais importantes estabelecimentos de ensino do Brasil no século XIX.

A rígida disciplina do internato não agradou ao menino. Em maio de 1888, ao ter notícias de que os escravos recém-libertados estariam depredando fazendas, fugiu para ir ao encontro de sua mãe. A indisciplina foi punida com a expulsão e Carlos foi transferido para o Ginásio São Francisco, em São João del-Rei, Minas Gerais.

Fundado pelo padre João Batista do Sacramento (1852-1907), o Ginásio São Francisco era uma renomada instituição de ensino e seu corpo docente reunia importantes nomes da intelectualidade são-joanense. Professor de latim e de história natural, o padre Sacramento foi uma figura marcante na formação do menino vindo de Oliveira.

Concluídos os estudos, Mariana decidiu que seu filho deveria formar-se em engenharia. Em 1895, Chagas ingressou no curso preparatório da Escola de Minas de Ouro Preto, tradicional centro de ensino superior. Os excessos da vida boêmia, contudo, custaram-lhe a reprovação nos exames e o retorno a Oliveira. Com a ajuda do tio médico e do avô, o jovem venceu a resistência da mãe e mudou-se para o Rio de Janeiro, capital federal, para estudar medicina. 
arlos Ribeiro Justiniano Chagas was born on July 9, 1878, on Bom Retiro Farm, about twenty kilometers from the city of Oliveira, Minas Gerais.

The eighteenth-century quest for gold opened many new routes in western Minas Gerais. The Goiás trail passed through the spot along the Maracanã River where Oliveira would be founded, at a point of many crossroads. The city is said to be named after a Portuguese man who started an inn around 1730 , where drovers and travelers could rest. Two decades later, those who had stayed behind erected a cross and later built Nossa Senhora de Oliveira chapel. This was the heart of the settlement that became a city in 1860.

Built in the latter half of the eighteenth century, Bom Retiro Farm was one of the first pieces of property established in Oliveira, even before the birth of the village that would later blossom into a city. Most of the farm's 7,700 hectares went to beef and dairy herds and sugarcane and coffee crops. Corn and beans were also planted, and there was a large variety of fruit trees.

Carlos Chagas's great-grandfather, Francisco das Chagas de Andrade, came to the region from his native Azores in the mid-eighteenth century. Romualda Chagas de Andrade was the oldest of the many children he had with his wife, Mariana Josefa Lobato. This daughter wed the Portuguese lieutenant Serafim Justiniano de Figueiredo, and they too had many children, one of whom was Carlos Chagas's father, José Justiniano Chagas. José Justiniano's first wife died early and he then married Mariana Candida Ribeiro de Castro, whose father, Carlos Ribeiro de Castro, owned a number of farms in the area, one of which was Bom Retiro.

Carlos Chagas was the oldest of the couple's four children. He was 4 when his father passed away. His mother took over the coffee crops on Bom Retiro and Bela Vista farms, the latter purchased by José Justiniano near the Minas city of Juiz de Fora.

Thanks to Carlos's close ties with his maternal uncles Cícero, Olegário, and Carlos_- "Uncle Calito" was a physician trained in Rio de Janeiro, with a clinic in Oliveira-he was an eager student from early on, with a keen interest in medicine. Eight-year-old Carlos knew how to read and write when he entered Colégio de São Luís, a boarding school run by Jesuits in Itu, rural São Paulo. Founded in May 1867, it was the religious order's second school in the country (the first was in Santa Catarina) and one of the most important teaching institutions in nineteenth-century Brazil.

The young boy did not take well to the boarding school's strict discipline. In May 1888, when he learned that recently freed slaves were going around laying siege to farms, he ran away from school to be with his mother. Expelled as a result, he was transferred to São Francisco School in São João del-Rei, Minas Gerais.

Founded by Father João Batista do Sacramento (1852-1907), São Francisco School was another prominent teaching institution, with important members of the local intelligentsia on its staff. Father Sacramento, a teacher of Latin and natural history, was an influential figure in the education of the lad from Oliveira.

Once Carlos had completed his studies, his mother Mariana decided he should go to college to study engineering. In 1895, he enrolled in the preparatory course at the Ouro Preto School of Mines, a traditional institute of higher education. But Carlos paid a price for living a bohemian lifestyle: he failed his final exams and had to return to Oliveira. With the help of his physician uncle and his grandfather, the young man prevailed over his mother's objections and moved to Rio de Janeiro, then the nation's capital, in order to study medicine. 

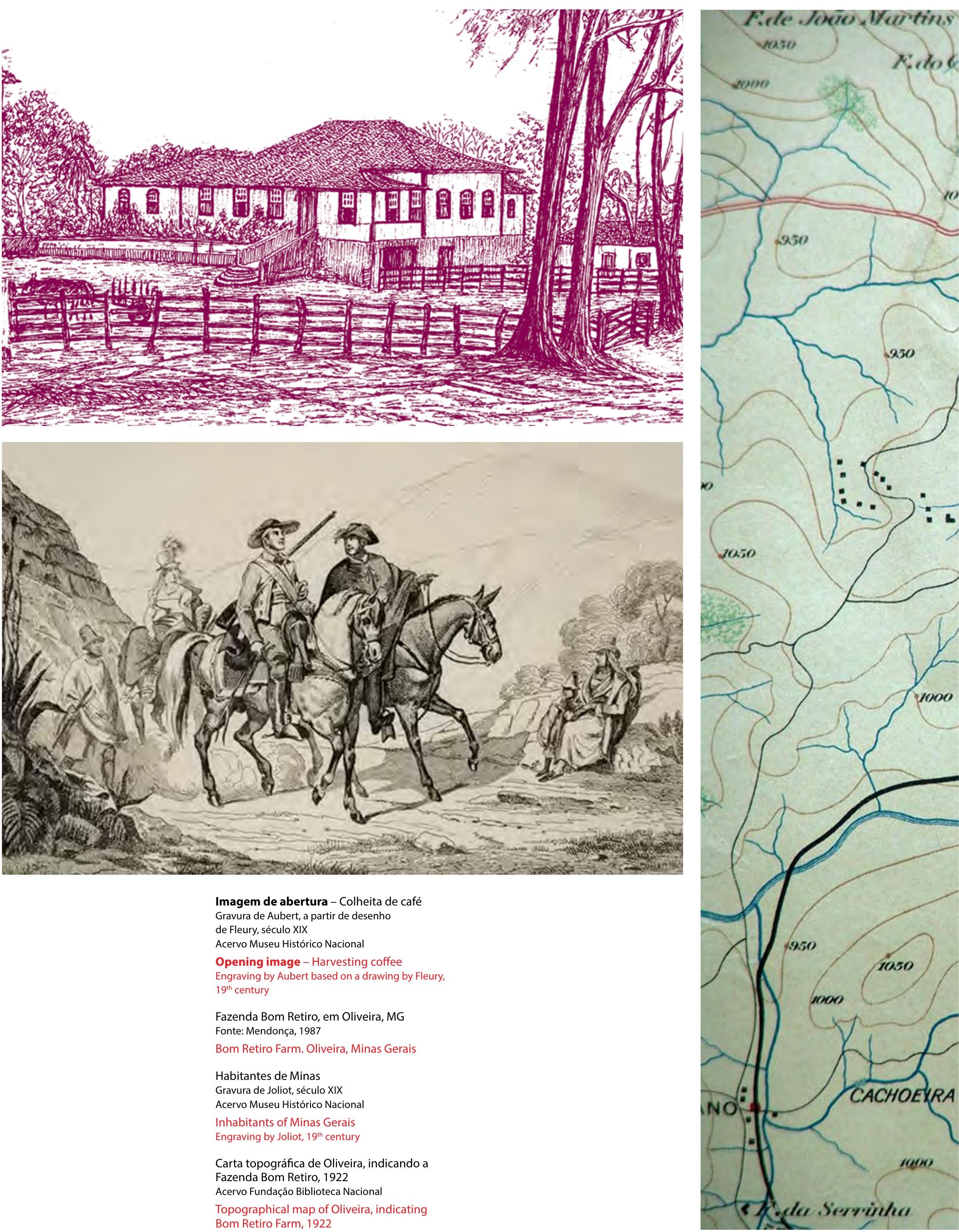

Imagem de abertura - Colheita de café

Gravura de Aubert, a partir de desenho

de Fleury, século XIX

Acervo Museu Histórico Nacional

Opening image - Harvesting coffee

Engraving by Aubert based on a drawing by Fleury,

$19^{\text {th }}$ century

Fazenda Bom Retiro, em Oliveira, MG

Fonte: Mendonça, 1987

Bom Retiro Farm. Oliveira, Minas Gerais

Habitantes de Minas

Gravura de Joliot, século XIX

Acervo Museu Histórico Nacional

Inhabitants of Minas Gerais

Engraving by Joliot, $19^{\text {th }}$ century

Carta topográfica de Oliveira, indicando a

Fazenda Bom Retiro, 1922

Acervo Fundação Biblioteca Nacional

Topographical map of Oliveira, indicating

Bom Retiro Farm, 1922
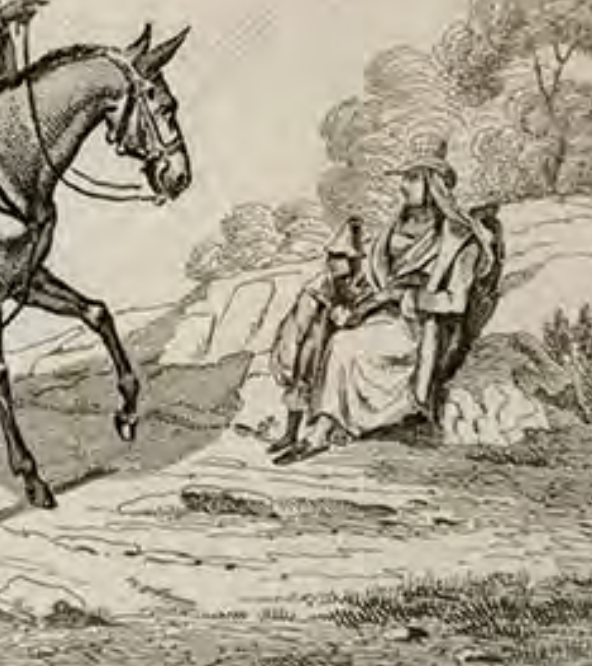


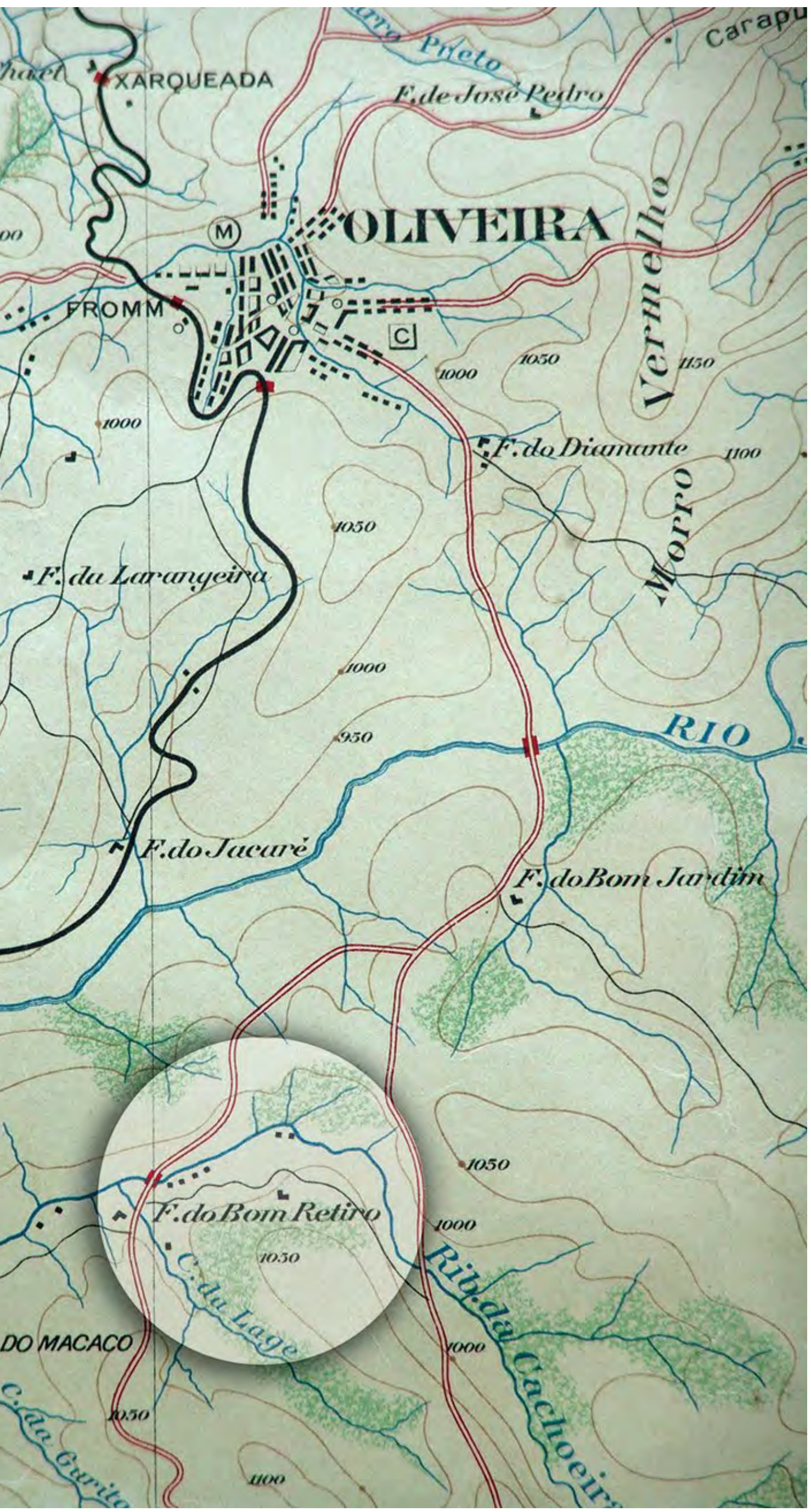

Oliveira ou Nossa Senhora da Oliveira (...) é uma das sucursais de São José, pequena cidade situada (...) a duas léguas de São João delRei. Pertence ao pequeno número das que não devem sua fundação à presença do ouro; deve-a unicamente às vantagens de posição. Com efeito, diversas estradas importantes passam por este ponto: a que vai de Barbacena à vila de Formiga, a do distrito de Rio Grande à cidade de Pitangui, de Rio de Janeiro e São João del-Rei a Goiás, de Vila de Campanha a Formiga etc. A vila de Oliveira está situada no meio de morros sobre o dorso de uma colina cujo cume é muito achatado.

Auguste de Saint-Hilaire

Oliveira, or Nossa Senhora da Oliveira (...), is part of the parish of São José, a small town lying (...) two leagues from São João del-Rei. It is among the few villages that does not owe its formation to the presence of gold; it owes it solely to the advantages of location. Indeed, several important roads pass through the place: the one from Barbacena to the village of Formiga, the one from the district of Rio Grande to the town of Pitangui, from Rio de Janeiro and São João del-Rei to Goiás, from Vila de Campanha to Formiga, etc. The village of Oliveira lies in the midst of hills, straddling a very flat-topped one. Auguste de Saint-Hilaire 


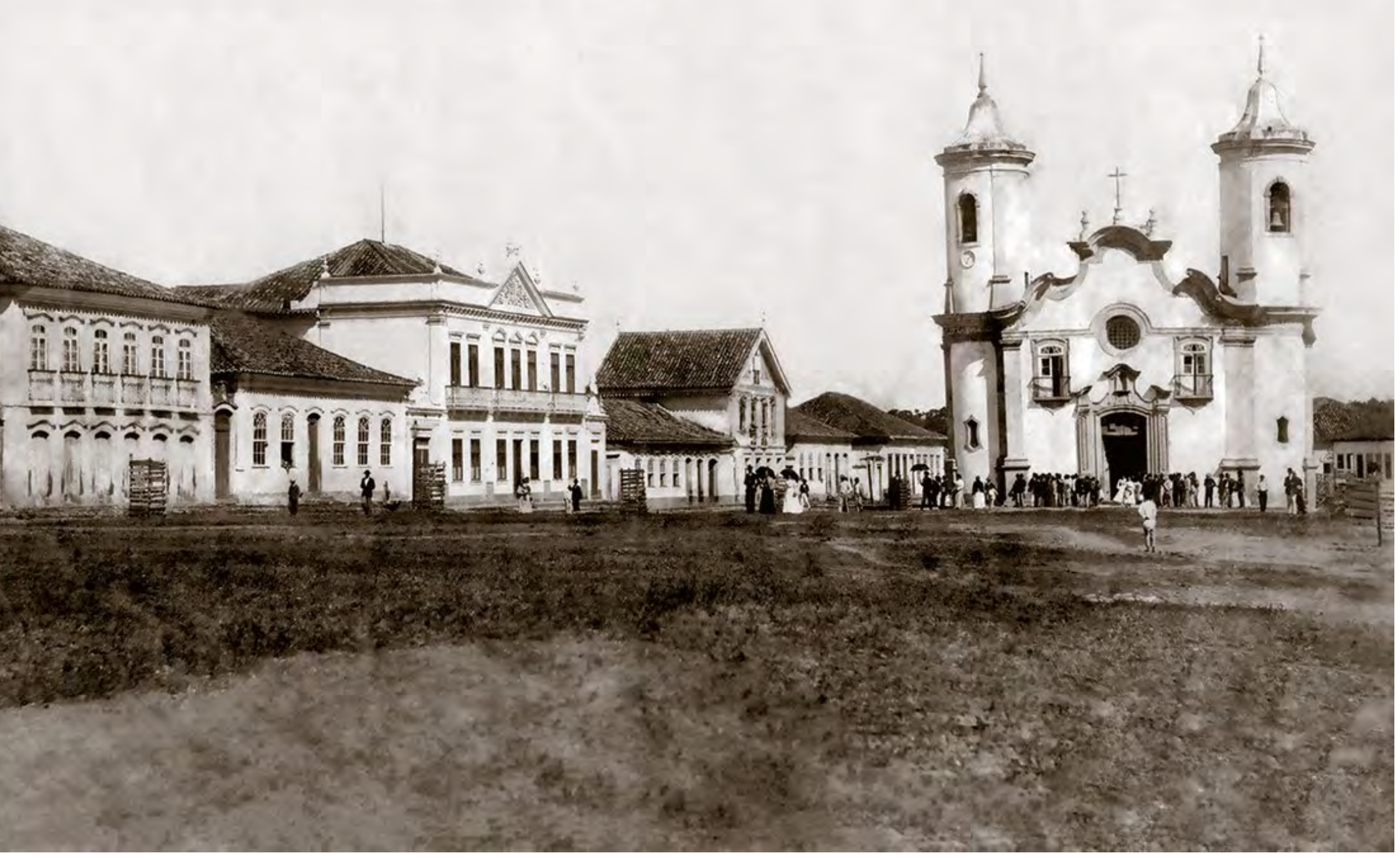

Matriz de Nossa Senhora de Oliveira, 1900 Acervo Fundaçăo Casa de Cultura Carlos Chagas

Nossa Senhora de Oliveira Cathedral, 1900 

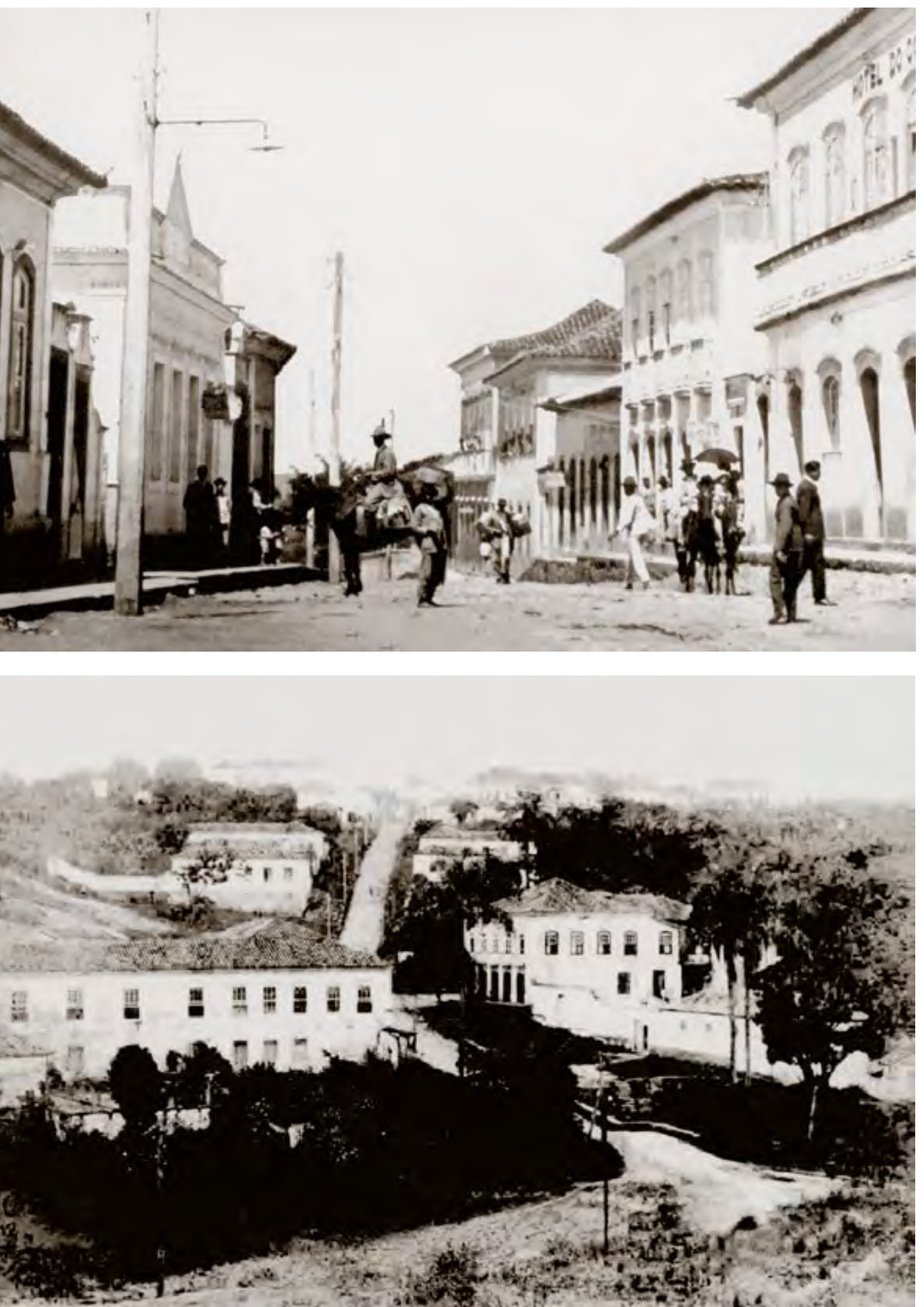

Rua Direita. Oliveira, década de 1910

Acervo Fundação Casa de Cultura Carlos Chagas

Direita Street, in Oliveira, 1910s

Ladeira dos Frades. Oliveira, década de 1920

Acervo Fundação Casa de Cultura Carlos Chagas

Ladeira dos Frades, a street in Oliveira, 1920s

Oliveira possui duas igrejas, das quais a principal foi construída no cume da colina, no meio da rua larga, e a igual distância das duas ordens de casas; é bastante bela no interior. Empregaram, para orná-la, uma pedra de um belo verde-maçã, que o mineralogista Pohl afirma ser, talvez, talco endurecido. Vêem-se em Oliveira diversas lojas de fazendas e mercearia que são bem sortidas, tavernas, uma farmácia e dois albergues, cada qual com seu rancho. Há aí também alfaiates, cordoeiros, serralheiros etc.

Auguste de Saint-Hilaire

Oliveira has two churches, the main one built at the crest of the hill, halfway along the main street and equidistant from two rows of houses; it is quite lovely inside. It is decorated with a beautiful apple-green stone, which mineralogist Pohl identifies as mineral talc. In Oliveira, one finds a number of very well-stocked fabric and grocery stores, some taverns, a pharmacy, and two inns, each with its own rancho [rustic building]. There are also tailors, rope makers, locksmiths, etc.

Auguste de Saint-Hilaire 


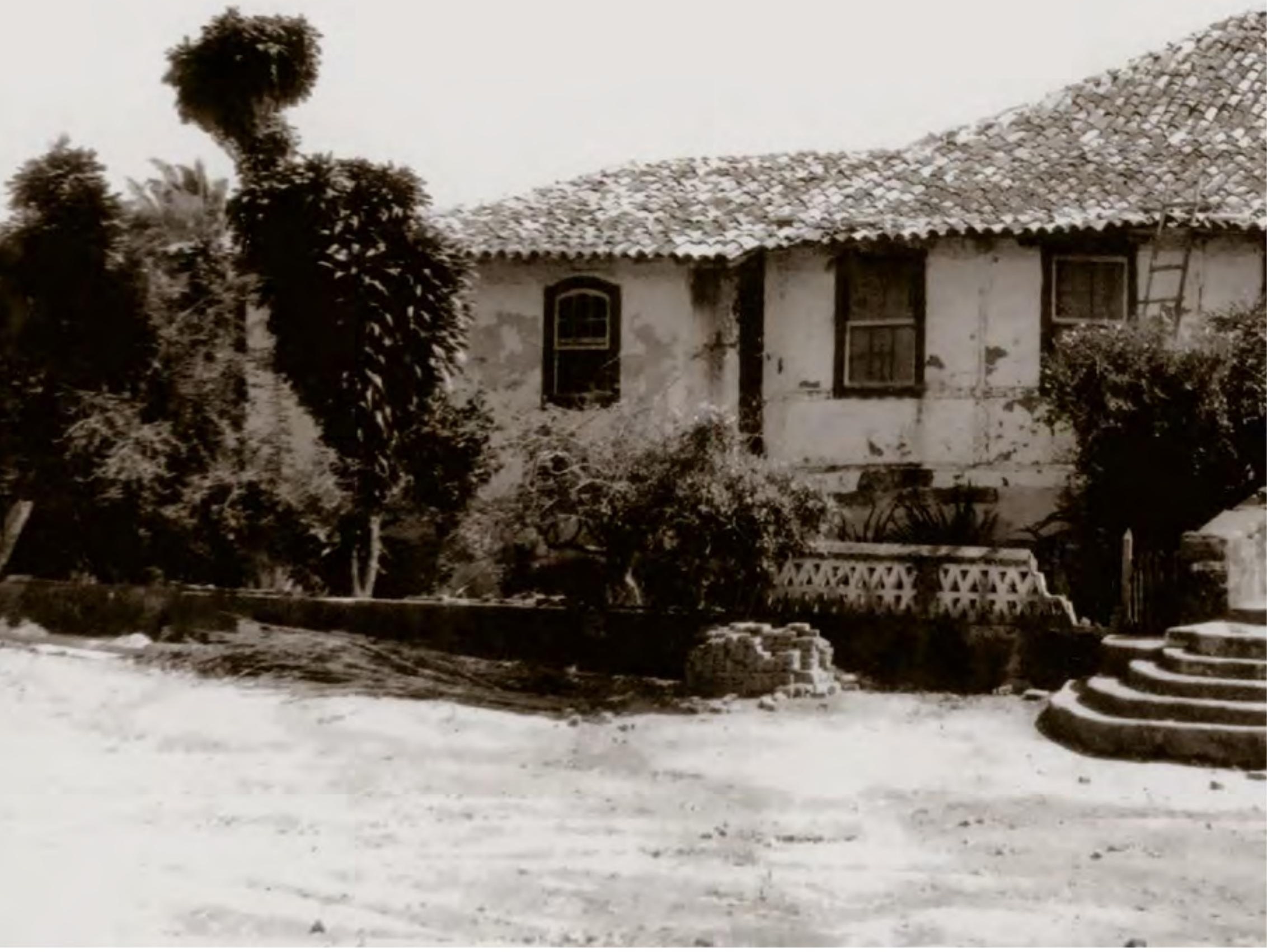




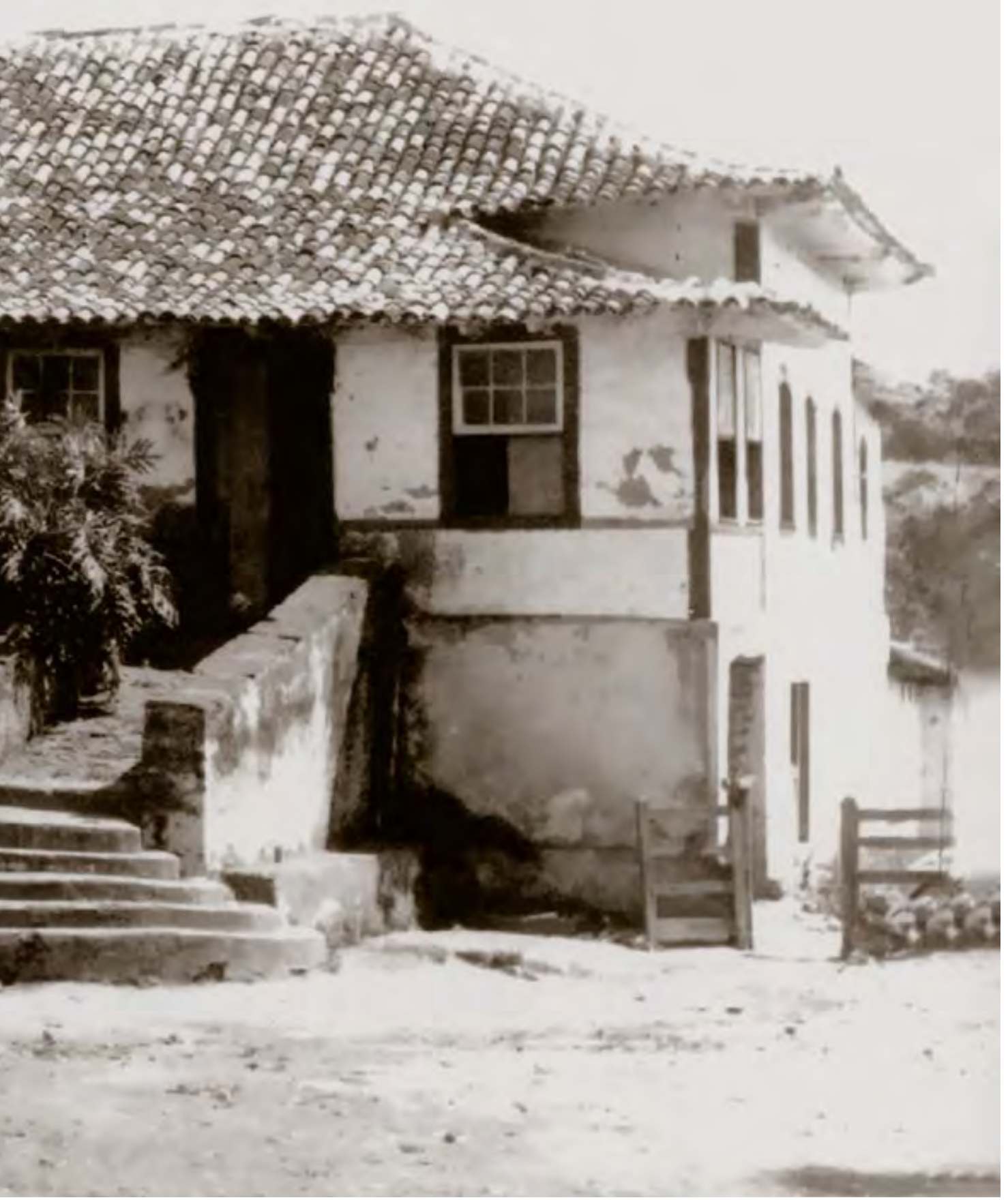

A rotina alimentar diária era respeitada rigorosamente. $\grave{A}$ alvorada, buscava-se o leite de ordenha recente, ainda tépido, cabendo ao visitante o privilégio de o saborear. Seguia-se o desjejum. Café, broa de milho e mingaus entretinham o estômago até a hora do almoço, servido ali pelas dez e meia. Merenda, fartamente acompanhada de deliciosos doces, dividia a segunda parte do dia. Após o jantar, semelhante ao almoço, o terço era puxado pelo patrão, a quem cabia sempre declamar os mistérios. Uma pequena ceia noturna preparava, para o leito, a gente cansada do trabalho diário.

Carlos Chagas Filho

The daily meals obeyed a strict routine. Fresh milk, still warm, was fetched at dawn, and the privilege of savoring it fell to visitors. Next came breakfast. Coffee, sweet cornbread, and porridges tided one over till lunch, which was served around ten thirty. A snack, generously accompanied by delicious sweets, divided the second part of the day. After supper, similar to lunch, the chaplet would be led by the master, who always prayed the Mysteries. A light evening meal got people who were tired from the day's work ready for bed.

Carlos Chagas Filho 


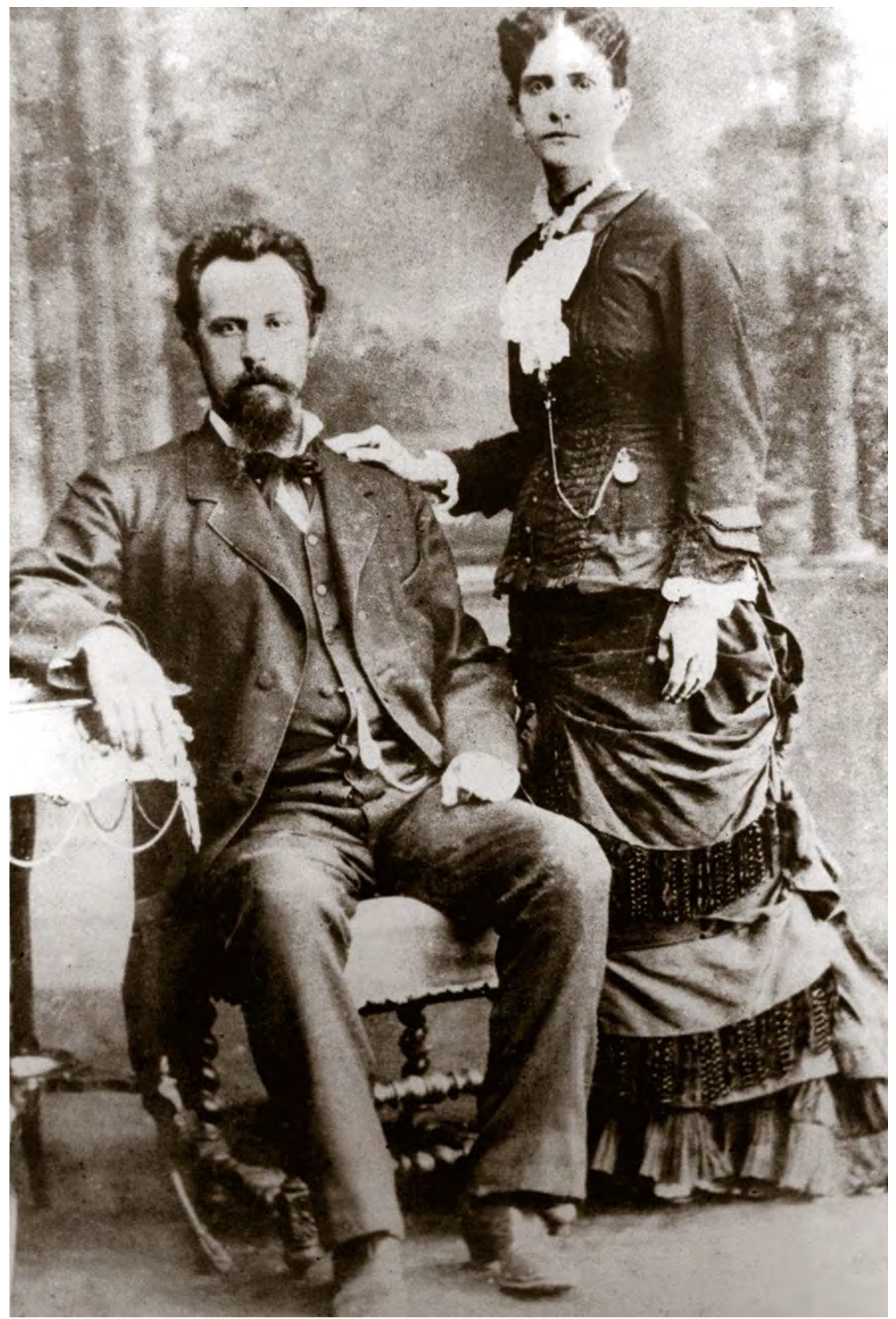

José Justiniano Chagas e Mariana Candida Ribeiro

de Castro Chagas, pais de Carlos Chagas

Acervo Casa de Oswaldo Cruz

Carlos Chagas's parents, José Justiniano Chagas and

Mariana Candida Ribeiro de Castro Chagas 


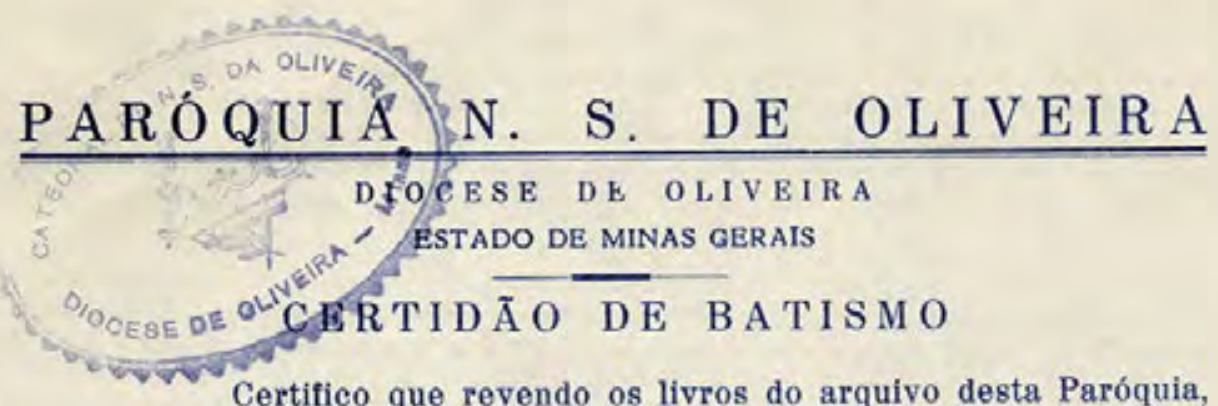
encontrei o teor seguinte:

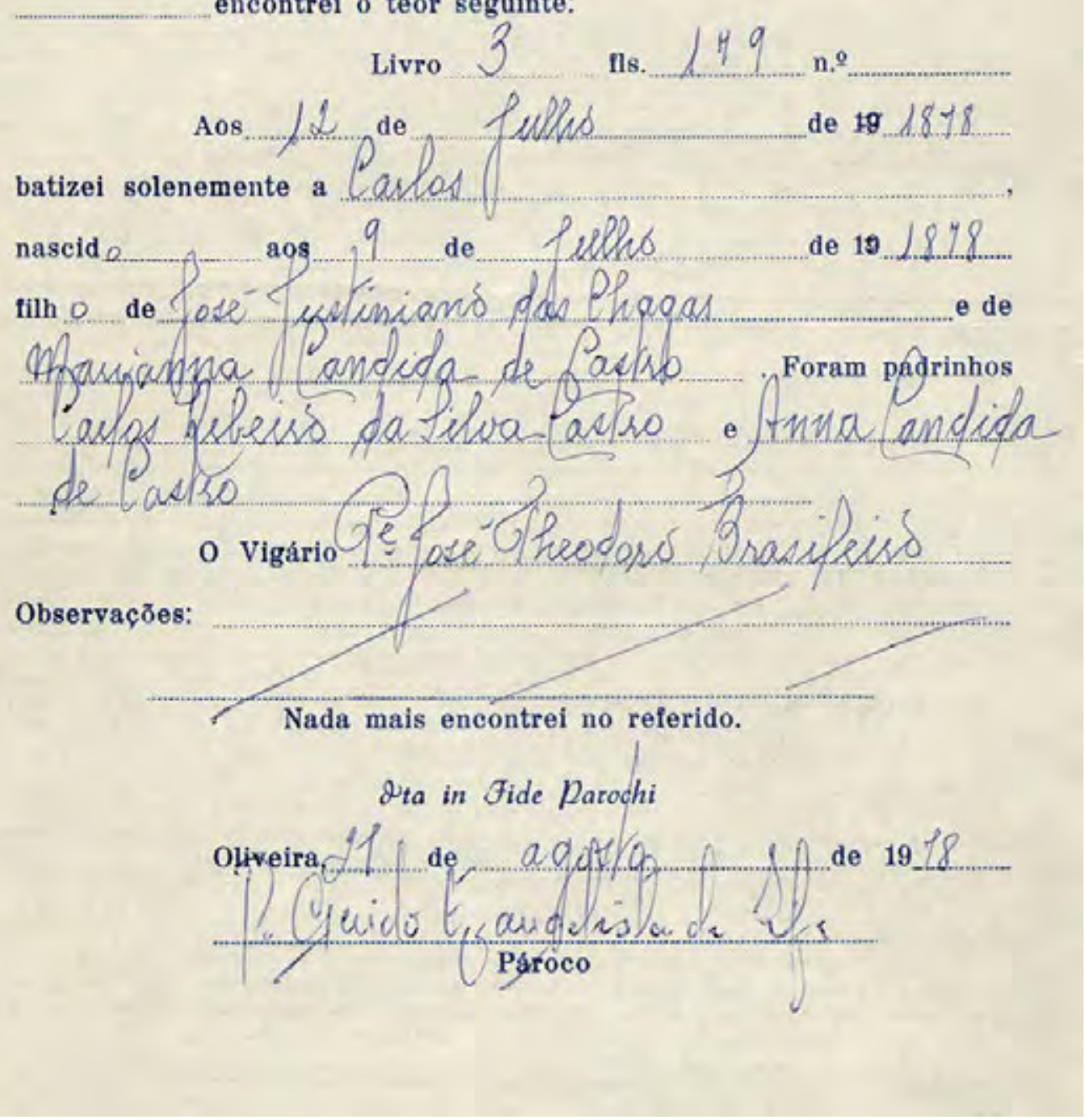

Certidão de batismo. Oliveira, 1878. Em 1979,

quando se comemorou o centenário de

nascimento de Carlos Chagas, Carlos Chagas Filho

recebeu de um primo de Oliveira esta certidão

que informava ter seu pai nascido em 1878 e

não em 1879, como era considerado até então Acervo Casa de Oswaldo Cruz

Baptismal certificate. Oliveira, 1878. In 1979,

during commemorations of the centennial of

Carlos Chagas's birth, Carlos Chagas Filho received

this certificate from a cousin in Oliveira; it states

that the scientist was born in 1878 , not 1879 ,

as previously believed

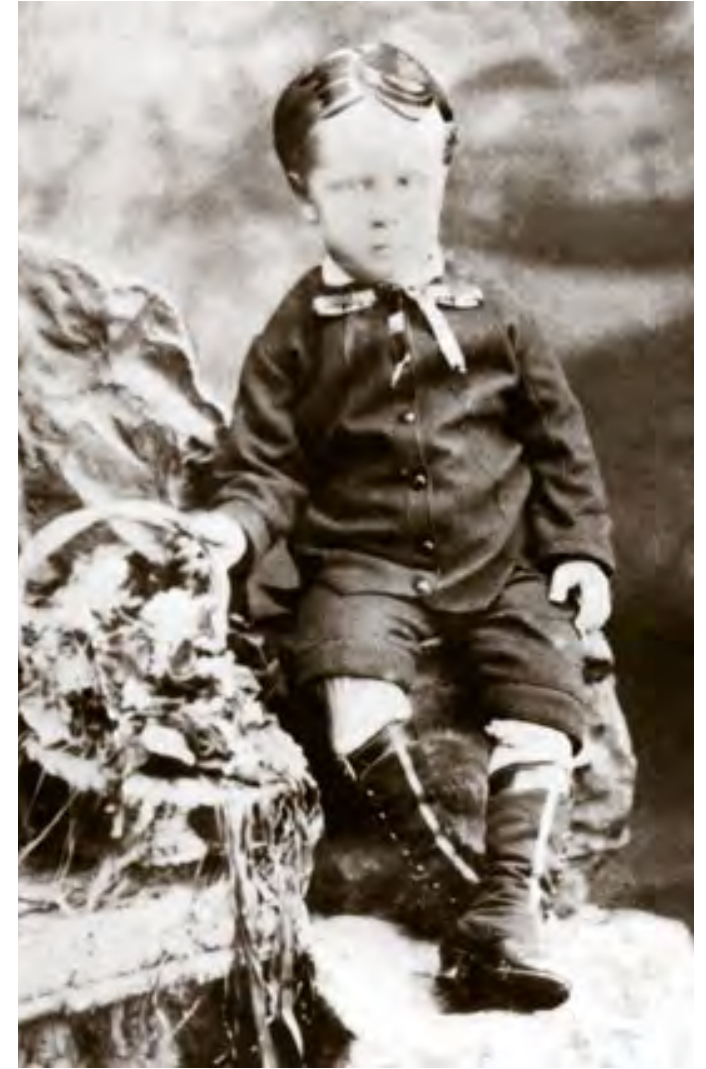

Carlos Chagas aos 4 anos Acervo Casa de Oswaldo Cruz Carlos Chagas at the age of 4 


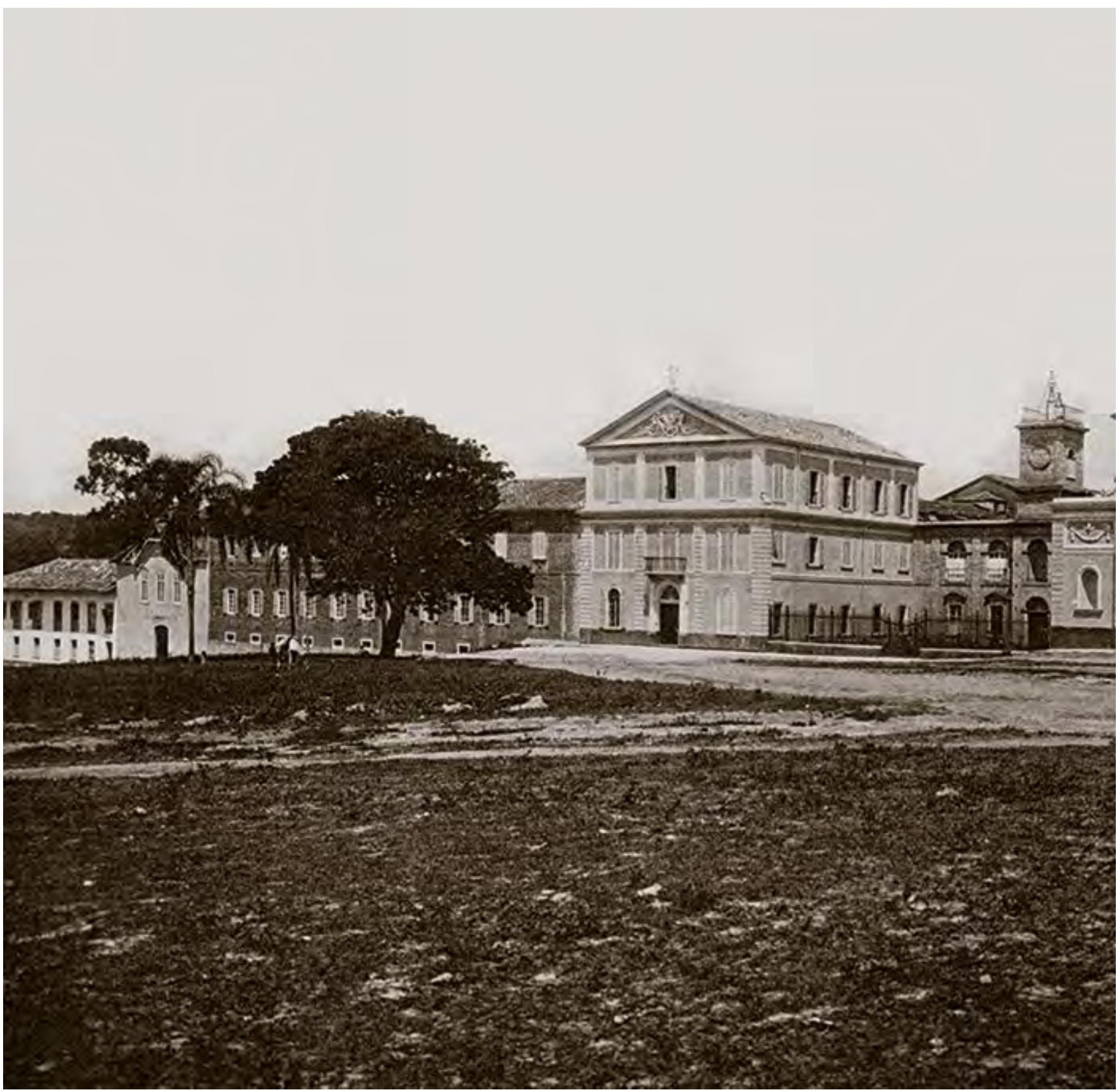

Colégio São Luís em Itu, SP, 1903

Acervo Associação dos Antigos Alunos da Companhia de Jesus

São Luís School in Itu, São Paulo, 1903 


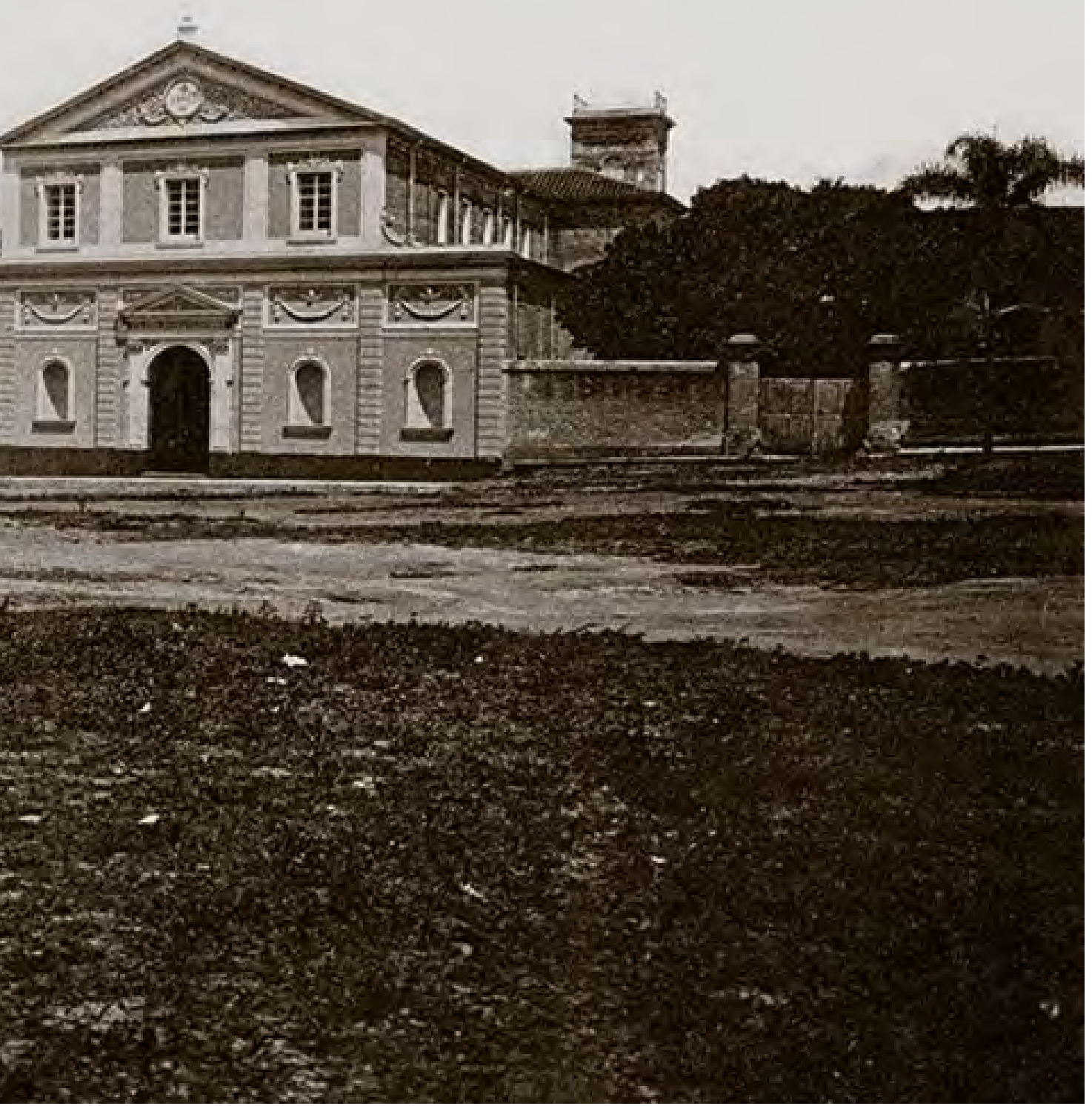

O Colégio de São Luís abrigava-se em vestuto casarão, que mais tarde (...) veio a servir de quartel da Força Pública do estado. As salas de aula eram grandes, o recreio aprazível, os dormitórios amplos e bem mantidos, mas a disciplina dos jesuítas não sabia bem ao menino de fazenda, acostumado à liberdade.

Carlos Chagas Filho

São Luís School was housed in a traditional old mansion, which later (...) came to serve as the barracks for the state Police Force. The classrooms were large, the recess area pleasant, the dormitories roomy and neat, but the Jesuit discipline did not sit well with the farm boy, accustomed to his freedom.

Carlos Chagas Filho 
... a alvorada às cinco horas, seguindo-se a missa, sempre longa. Do desjejum, servido somente às sete e meia, passava-se às aulas das oito às 12 e trinta, quando se servia o almoço, que, como o jantar, era frugal e, mais ainda, a merenda, dada às cinco e meia da tarde. Depois do recreio (...) continuava-se a estudar até as oito e meia da noite. Antes de dormir, os meninos tinham direito a uma xícara de chá, sem nada. (...) Mesmo sem apreciá-la, Chagas procurou integrar-se na vida do colégio. Participou das atividades da Arcádia Gregoriana, fundada em 1882, associação destinada ao fomento das letras clássicas, onde os alunos de maior pendor podiam dedicar-se à leitura de seus escritos em prosa e verso ou ao exercício da expressão oral (...).

Carlos Chagas Filho

(...) sunrise at five o'clock, followed by mass, always long. From breakfast, served only at seven thirty, one went on to classes from eight until twelvethirty, when lunch was served, meager like dinner, and, more meager still, the afternoon snack, which came at five thirty. After recess, (...) the studying continued until eight thirty at night. Before bed, the boys had the right to a cup of tea, with nothing else. (...) Even though he didn't enjoy it, Chagas tried to join in school life. He took part in the activities of the Gregorian Arcady, founded in 1882, an association that fostered the classics and where the more inclined pupils could dedicate themselves to reading their writings in prose and verse or to practicing verbal expression (...).
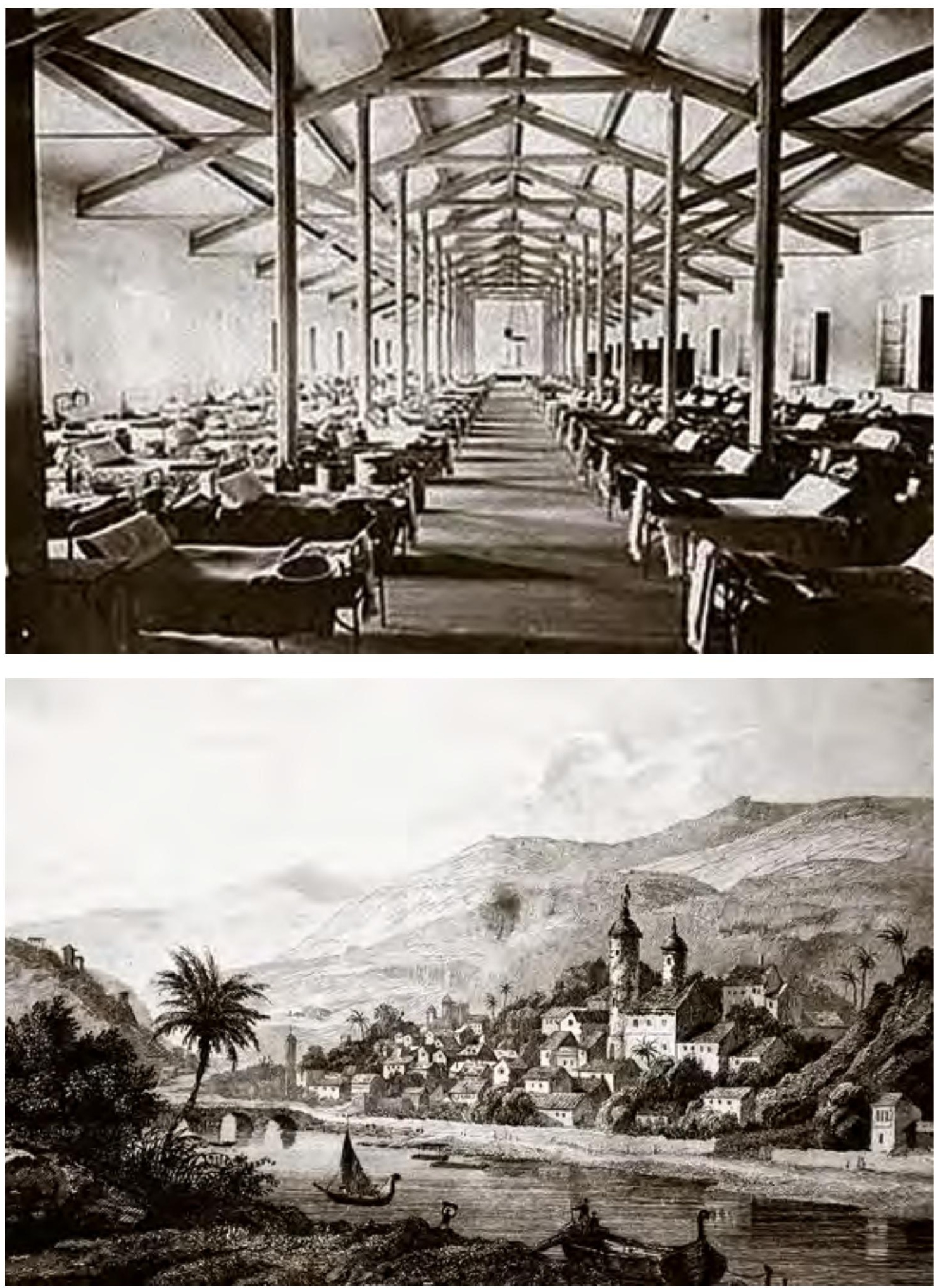

Dormitório dos alunos no Colégio São Luís. Itu, 1903

Acervo Associação dos Antigos Alunos da Companhia de Jesus

Student dormitory, São Luís School. Itu, 1903

Vista de São João del-Rei, MG

Gravura de François Hippolyte Lalaisse a partir de desenho de Van der Burch, século XIX

Acervo Museu Histórico Nacional

View of São João del-Rei, Minas Gerais

Engraving by François Hippolyte Lalaisse based on a drawing by Van der Burch, $19^{\text {th }}$ century 

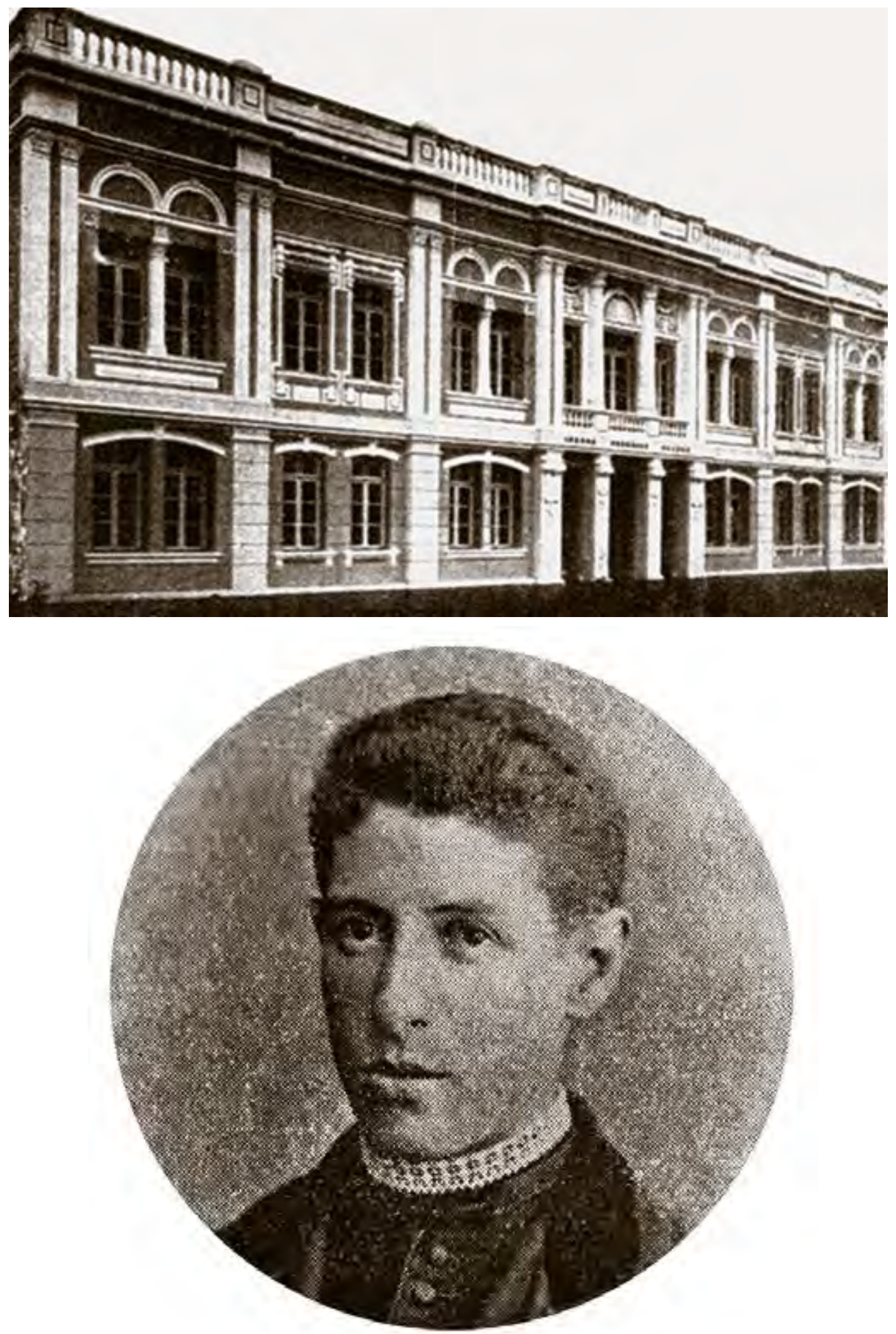

Foi em São João que Chagas ouviu falar, pela primeira vez, em Machado de Assis. Sacramento dava aos seus estudantes uma semente de estímulo intelectual e de amor pelas coisas brasileiras que iria segui-los pela vida afora. Foi assim com Chagas. (...) Marca a vida no Colégio São Francisco as páginas mais alegres da adolescência de meu pai.

Carlos Chagas Filho

It was in São João that Chagas first heard of Machado de Assis. Sacramento instilled in his students the seed of intellectual motivation and love for what is Brazilian, something that would stay with them throughout their lives. That's how it was with Chagas. (...) My father's life at São Francisco School marked the happiest pages of his adolescence.

Carlos Chagas Filho

Ginásio São Francisco, em São João del-Rei Acervo Universidade Federal de São João del-Rei São Francisco School, in São João del-Rei

Padre João Batista do Sacramento, fundador e diretor do Ginásio São Francisco Fonte: Braga, 1913

Acervo Fundação Biblioteca Nacional

Father João Batista do Sacramento, founder and director of São Francisco School 
Carta de Carlos Chagas para sua mãe

Acervo Casa de Oswaldo Cruz Letter from Carlos Chagas to his mother

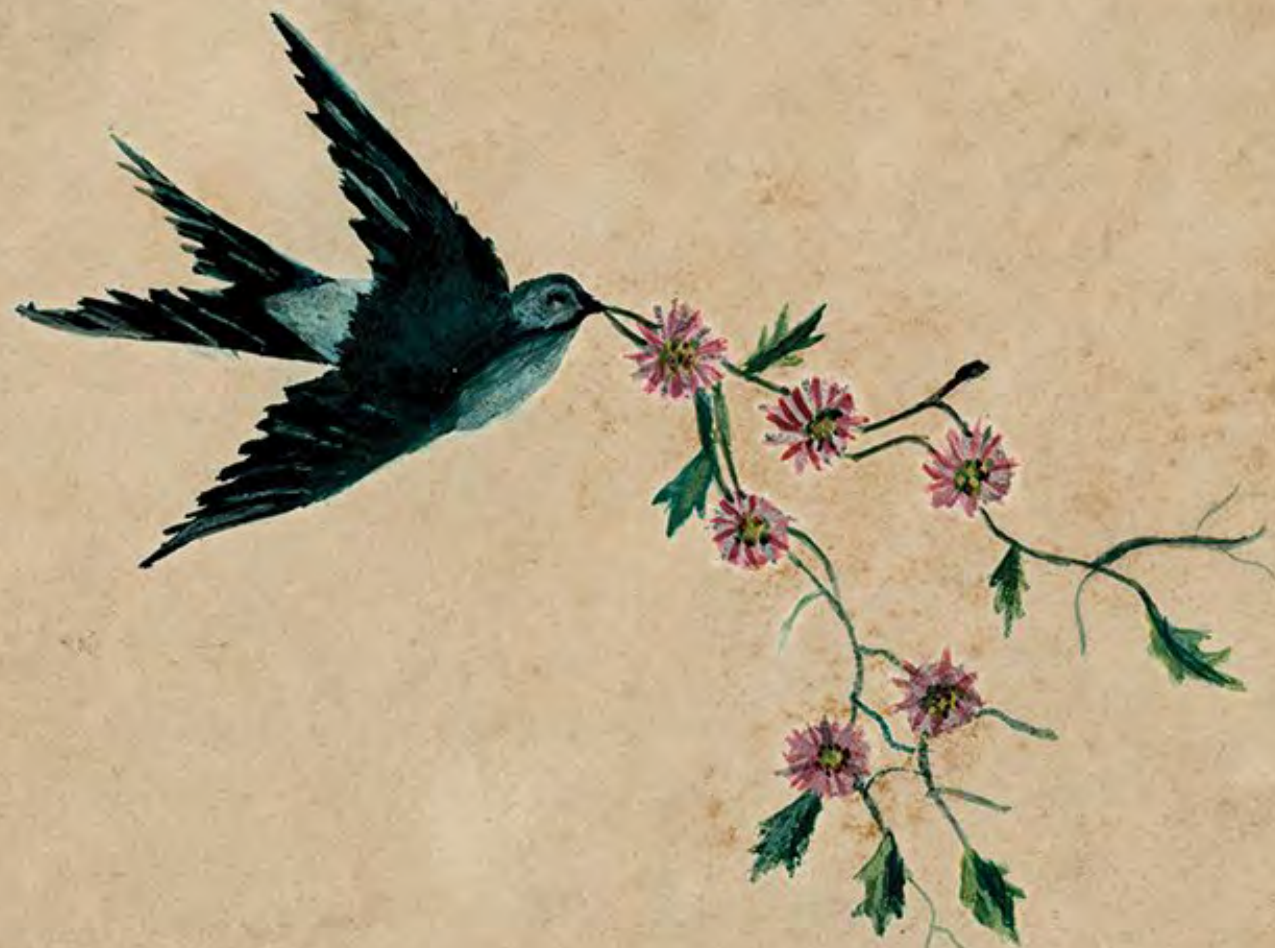

$\xi_{x}: h^{2}$

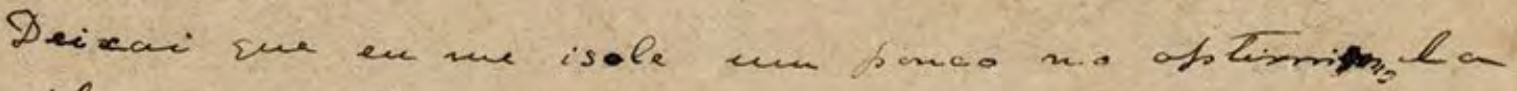

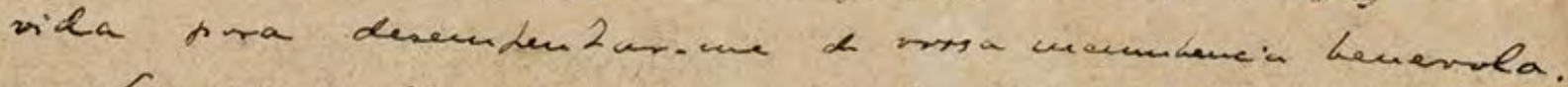
Gs encautas de una munt = Fotrieal, en ghe o

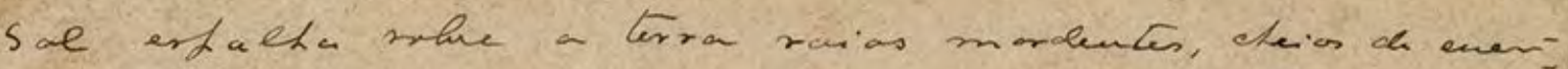
sia creacora, un sue o merde naturale bubra a

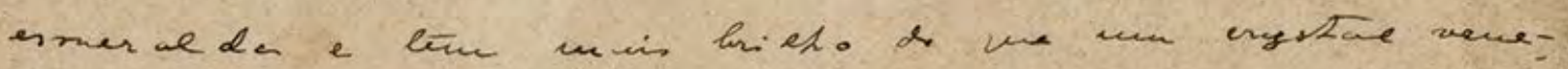

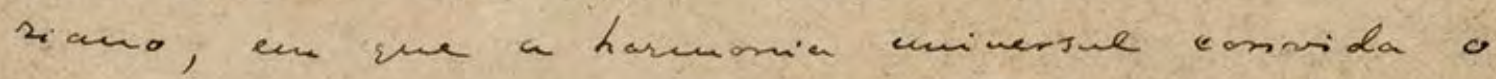

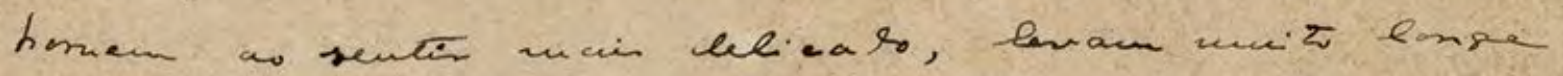
- Leusanento, suando illunina-o clarilad intansa Le un uffers, as soro de renctuas suil, easintosa:

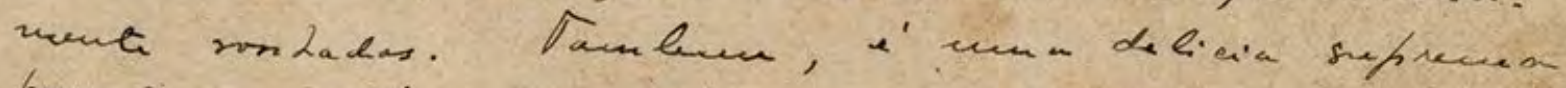

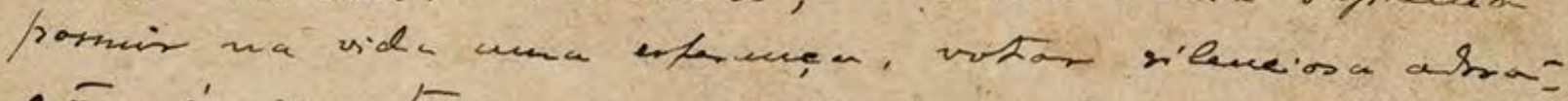

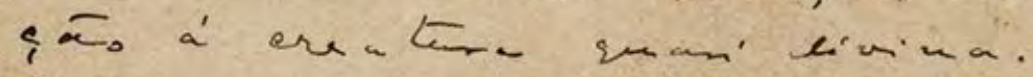

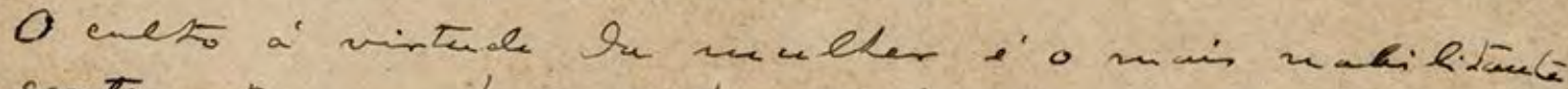
surtiment sue hoch o hamen Lamin, a surele whe unfindo a alena o misiticas ersenerin, illumerima a

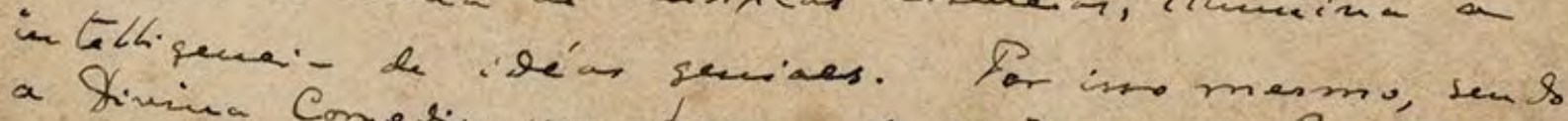

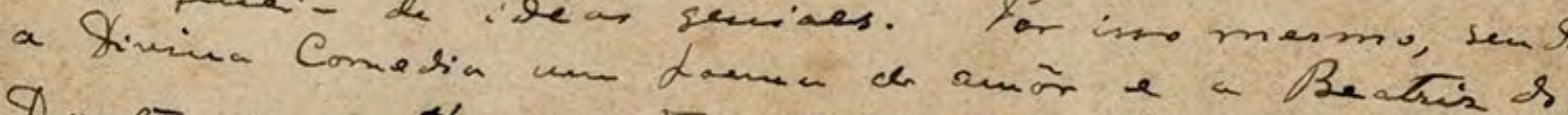

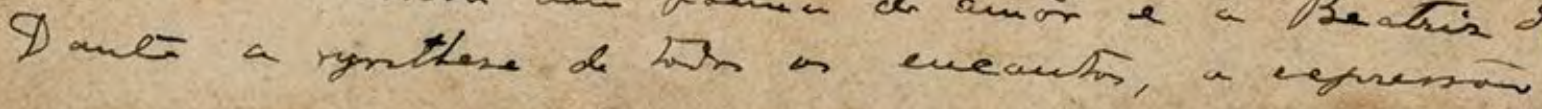


1- UM MENINO DO INTERIOR DE MINAS | A BOY FROM RURAL MINAS GERAIS

de un sorriso la Divindade, metka insfirarm-se

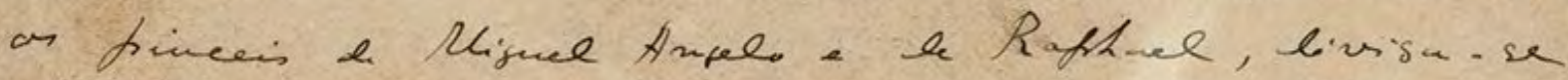

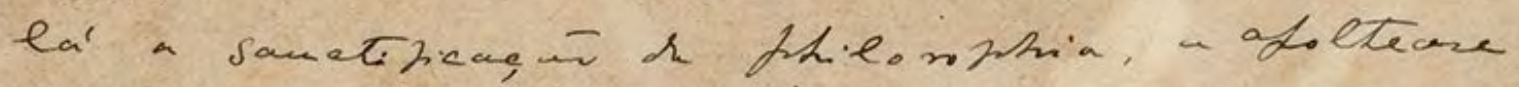

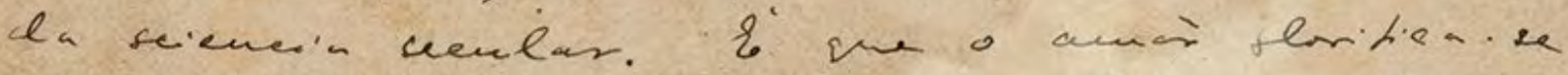

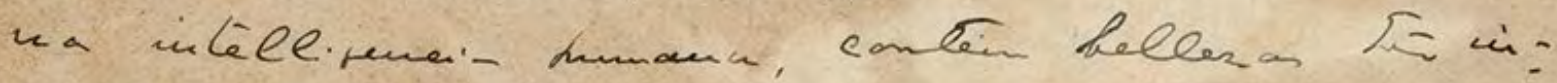

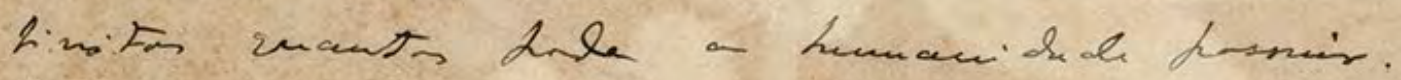

Le alguma mes, na pratica ob heen, o domen leixare

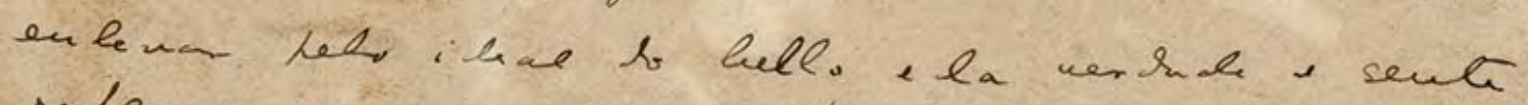

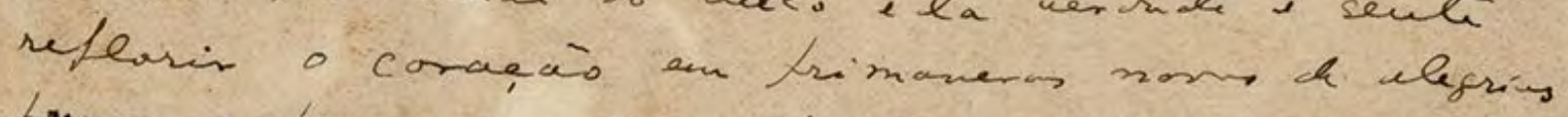
fress e prazeres suaves, $e^{\prime}$ see ra is th acomdanta.

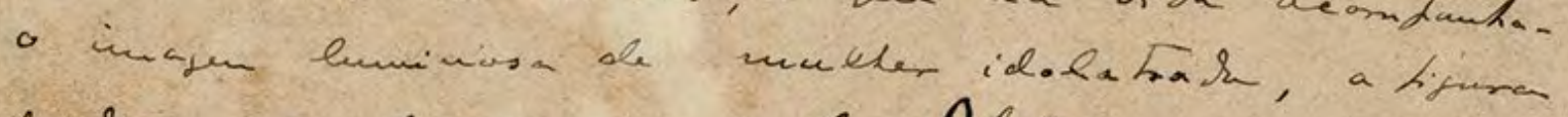
ratias e diminsisina de Mläe.

tearlas teasas.

41 